Yuriy Melnyk, Yuriy Prokopenko, Anatoly Stadnik. Logistics educational opportunities and new neurobiological approaches.

We consider teaching logistics as a separate scientific field. Analyzed scientific publications and current research on teaching logistics. It solved the problem of teaching logistics and feasibility of the neurobiological approach.

Key words: pedagogical logistics, information and educational space, information system, neurobiological approach.

Стаття надійшла до редакційної колегії 01.09.2015

УДК 316.74+613.67-057.875::355.23

(C) Мельник Ю. Б., Свячена С. М., 2015.

Мельник Юрій Борисович

Національна академія Національної гвардії України

Свячена Світлана Михайлівна

Харківська гімназія № 12

\title{
ФОРМУВАННЯ КУЛЬТУРИ ЗДОРОВ'Я СТУДЕНТІВ У ВНЗ
}

Висвітлено проблему формування культури здоров'я у студентів. Виявлено особливості формування культури здоров'я студентів у вищих навчальних закладах. Запропоновано принципи формування культури здоров'я студентів у вищих навчальних закладах. Введено до наукового обігу поняття «культура здоров'я студента».

Ключові слова: культура здоров'я, принципи формування культури здоров'я, культура здоров'я студента.

Актуальність проблеми формування культури здоров'я зумовлена самою природою цього питання, оскільки здоров'я потребує не лише піклування, а і культивування. Через це поняття здоров'я часто-густо вживається разом зі словами збереження та зміцнення. Саме в такому контексті поняття здоров'я набуває суттєвого значення, оскільки за цих умов відбувається розвиток важливих особистісних якостей, на противагу ним - деградація, хвороба, смерть. Тому формування культури здоров'я є важливим питанням для людини будь-якої сфери діяльності.

Meта статmi - розкрити проблему формування культури здоров'я студентів у вищих навчальних закладах (далі - ВН3); визначити принципи формування культури здоров'я студентів у ВНЗ, ввести до наукового обігу поняття «культура здоров'я студента».

Зміни, що відбуваються у освітній галузі в зв'язку 3 ii реформуванням, ставлять перед педагогічною наукою цілу низку 
нових питань, вирішення яких потребує підвищення ефективності підготовки студентів у ВНЗ.

Оскільки становлення компетентності особистості починається ще під час навчання у школі та продовжується у ВНЗ, де здійснюється вплив на мотиваційну, поведінкову та інші сфери особистості студента, а також формуються професійні уміння та навички, то й особливу увагу слід приділяти всебічному розвитку студента саме в цей час. Підвищенню ефективності навчання, всебічному i гармонійному розвитку студентів сприятиме формування в них культури здоров'я.

Формування культури здоров'я студентів у ВНЗ - це не лише формування мотивації та ціннісних орієнтацій студента щодо здоров'я, якостей його характеру, звичок, поведінки, а i шлях до вирішення важливих питань виховання особистості в соціумі, формування гуманних взаємовідносин між людьми, що безумовно забезпечуватиме становлення професіоналізму, відповідальності, зміцнення дисципліни тощо. Розробка методологічних та теоретичних засад 3 проблеми формування культури здоров'я [1;2] дозволила нам обгрунтувати та ввести до наукового обігу поняття культура здоров'я студента.

Культура здоров'я студента - інтегроване особистісне утворення, сформоване на основі знань і умінь, характеризується здоров'яформувальною поведінкою, що відповідає індивідуальним особливостям особистості студента, виявляється в цілісності та гармонійному розвиткові всіх складових індивідуального здоров'я (фізичного, психічного, соціального, духовного), основних сфер особистості (мотиваційної, когнітивної, афективної, ціннісної, поведінкової), прагненні студента до самопізнання, самовдосконалення.

Вкрай важливим є визначення принципів формування культури здоров'я студентів у ВНЗ та шляхів їх реалізації, впровадження яких, на нашу думку, забезпечуватиме створення здорового освітнього середовища [3] та сприятиме ефективному формуванню гармонійно розвиненої особистості студента.

Охарактеризуємо кожний з принципів:

1. Взаємопроникнення та взаємозумовленість рівнів культури здоров’я. Цей принцип вказує на те, що між рівнями культури здоров'я існує інтеграційний зв'язок. Культура здоров'я вищого рівня впливає на культуру здоров'я нижчого, проте, від нижчих рівнів залежать вищі. Оскільки особистість є соціальним суб'єктом, яка виступає творцем суспільної культури, зокрема культури здоров'я родини, громади, нації, людства.

Шляхи реалізації принцчипу:

- Сприяння розвиткові культури здоров'я особистості студентів. 


\section{Збірник наукових статей}

- Проведення виховних заходів та впровадження навчальних програм, які б залучали молодь до надбань культури здоров'я родини, суспільства, нації.

2. Взаємовпливу та взаємодії культури здоров'я викладачів i студентів. Цей принцип передбачає залучення всіх суб'єктів освітнього процесу до співпраці та взаємодії, що сприятиме інтеграції та засвоєнню культури здоров'я оточення відповідно до соціокультурного середовища, розвиватиме активність і безпосередньо впливатиме на становлення культури здоров'я студента.

\section{Шляхи реалізаиії приничипу:}

- Наслідування традицій та правил суспільства, сім'ї щодо збереження та зміцнення здоров'я.

- Особистий приклад викладачів у формуванні культури здоров'я студентів.

3. Спрямованості культури здоров'я на розвиток особистості студента. Цей принцип передбачає залучення всіх студентів до здобутків культури здоров'я, що сприятиме розвиткові особистості кожного 3 них. Він полягає в тому, що в освітньому процесі педагогічний колектив здійснює цілеспрямований вплив на студентів через залучення їх до основ національної культури здоров'я, що забезпечує сприятливі умови для всебічного розвитку особистості студента.

\section{Шляхи реалізачії принцииу:}

- Цілеспрямованість та систематичність соціально-педагогічної діяльності педагогічного колективу з проблеми формування культури здоров'я.

- Проведення психолого-педагогічного моніторингу розвитку в особистості інструментальних, міжособистісних, спеціальних компетенцій.

4. Впровадження навчальних дисциплін (наприклад, "Базиси культури здоров'я”) та спецкурсів про культуру, людину та її здоров'я для студентів у ВНЗ. Цей принцип розкриває та забезпечує субстанціональну єдність різних навчальних дисциплін щодо питань культури здоров'я, сприяє оволодінню та систематизації студентом знань про людину, суспільство, культуру.

Шляхи реалізації принцииу:

- Врахування міжпредметних зв'язків у процесі навчання студентів ВНЗ.

- Розробка та впровадження дисциплін, спецкурсів про культуру, людину та ії здоров'я, спрямованих на всебічний розвиток особистості студентів.

5. Відповідності навчального навантаження особистому стану здоров'я студента (не нашкодь!). Цей принцип вимагає врахування 
стану фізичного, психічного, соціального, духовного здоров'я студента, сприяє вирішенню питань збереження здоров'я студентів у освітньому процесі вищого навчального закладу.

Шляхи реалізації принципу:

- Проведення психолого-педагогічного моніторингу i діагностування студентів.

- Створення сприятливого освітнього середовища щодо збереження та зміцнення здоров'я студентів.

6. Спрямованості соціального виховання на формування культури здоров'я студентів. Цей принцип передбачає залучення виховного потенціалу соціального середовища та створення спеціальних умов для цілеспрямованого формування культури здоров'я студентів у освітній діяльності вищого навчального закладу.

Шляхи реалізаиії принципу:

- Врахування факторів соціокультурного середовища, а також основних чинників формування культури здоров'я студентів.

- Створення матеріальних, духовних, організаційних та інших умов для формування культури здоров'я студентів.

7. Гармонії та цілісності фізичного, психічного, соціального, духовного здоров'я студента. Цей принцип спрямований на гармонійний розвиток усіх складових особистості студента, сприяє цілісності взаємовідношень між усіма його сферами, вказує на необхідність гармонійного впливу на різні сфери особистості студента, зберігаючи і розвиваючи їх як єдине ціле.

Шляхи реалізаиії принцииу:

- Створення сприятливих умов для всебічного, гармонійного розвитку студентів. Реалізація програм 3 розвитку та корекції особистості студента.

- Стимулювання студентів до самопізнання, самовдосконалення, творчої діяльності на основі сучасних наукових досягнень психології та педагогіки.

Розробленість теоретико-методологічних положень означеної проблеми забезпечуватиме системність та цілеспрямованість цієї діяльності, що сприятиме реалізації провідної ідеї - створенню здорового освітнього середовища у вищих навчальних закладах та формуватиме культуру здоров'я студентів. Ця діяльність забезпечуватиме розвиток особистості, допомагатиме збереженню та зміцненню здоров'я студентів. Одним 3 найефективніших засобів вирішення цієї проблеми вбачаємо створення в освітніх закладах як здорового освітнього середовища, так і культивування в ньому індивідуально-соціально-духовного здорового способу життя студентів, що базуватиметься на вищезазначених принципах формування культури здоров'я. 
Таким чином, розкрито особливості формування культури здоров'я студентів у ВНЗ, запропоновані принципи формування культури здоров'я студентів у ВНЗ, введено до наукового обігу поняття «культура здоров'я студента».

Багатогранність і багатоаспектність цієї діяльності відкриває великі перспективи для вивчення й проведення подальших досліджень за цією тематикою. В цій статі ми лише порушили проблему, яка потребує подальшого вивчення, зокрема, визначення особливостей, критеріїв, показників, розробки методик дослідження формування культури здоров'я студентів.

\section{Література}

1. Мельник Ю. Б. Феномен „культура здоров'я” (методологічний та методичний аспекти) / Ю. Б. Мельник // Всемирный Этический Форум „Этика и гуманизм” : сб. тр. междунар. конгр., 25-29 апр. 2005 г. - Алушта, 2005. - С. 177-179.

2. Мельник Ю.Б. Діалектика здоров'я / Ю.Б. Мельник // Всемирный Этический Форум «Единый мир - здоровый человек» : сб. тр. междунар. конгр., 27-30 апр. 2004 г. - Ялта, 2004. - С. 214-216.

3. Мельник Ю. Б. Щодо ідеї створення здорового освітнього середовища / Ю. Б. Мельник // Новий колегіум : наук.-інформ. журнал. - Х. : ХНУРЕ, 2013. - № 3 (73). - C. 21-25.

Юрий Мельник, Светлана Свяченая. Формирование культуры здоровья у студентов высших учебных заведений. Освещена проблема формирования культуры здоровья у студентов. Выявлены особенности формирования культуры здоровья у студентов в высших учебных заведений. Предложены принципь формирования культуры здоровья студентов в высших учебных заведениях. Введено в научный оборот понятие «культура здоровья студента».

Ключевые слова: культура здоровья, принципь формирования культуры здоровья, культура здоровья студента.

Yuriy Melnyk, Svitlana Sviachena. Forming of the culture health of students in universities.

Illuminating problem of formation of culture health in the students. The revealed features of formation of culture health in the students in the universities. Are proposed principles of formation culture of health of students in universities. Permission for into scientific circulation concept of «culture of health student».

Key words: culture of health, principles of formation culture of health, culture of health student.

Стаття надійшла до редакційної колегії 10.09.2015 